\title{
The Relationship Between the Ability of Understanding Mathematical Concepts With Language Ability During Contextual Learning
}

\author{
Salmaini S. ${ }^{1 *}$, Ahmad Fauzan ${ }^{1}$, I Made Arnawa ${ }^{1}$, Darmansyah ${ }^{1}$, and \\ Widada $^{2}$
}

${ }^{I}$ The Doctoral Program of Education, Universitas Negeri Padang, Indonesia

${ }^{2}$ Postgraduate Program of Mathematics Education, Universitas Bengkulu, Indonesia

*Corresponding author. Email: salmaini.salma@ gmail.com

\begin{abstract}
Increasing the ability of the left brain can have a positive effect on the understanding of mathematical concepts. The purpose was to test whether there was a positive direct effect on students' language skills through contextual learning based on Padang (Pariaman) Tabuik Culture on their ability to understand mathematical concepts. It was survey research. The sample was selected simple random as many as 100 people from 389 students of SMA N 3 Padang Indonesia. The sample has attended lectures through contextual learning based on Padang Tabuik culture for 8 weeks. The research instrument was a test of language skills and the understanding of mathematical concepts. Quantitative data were analyzed using a structured equation model. It is analyzed using a Lisrel application program. The conclusion of this study is that students' language skills through contextual learning based on Padang Tabuik Culture have a positive direct effect on their ability to understand mathematical concepts.
\end{abstract}

Keywords: Conceptual comprehension ability, Language ability, Contextual learning.

\section{INTRODUCTION}

The concepts of mathematics were a difficult learning object for students. Even though the concept is a mathematical object that cannot be avoided by students. One of the reasons is the abstract mathematical object [1]. The concept of mathematics is abstract, it is very possible for him to have misconceptions. Students learning mathematical concepts need relational understanding, so that it can lead to misunderstandings and difficulty learning [2].

To overcome students 'mistakes and misconceptions in learning mathematics is through learning that is close to the students' minds. Students can do the mathematical process horizontally [3][4]. Such learning will improve students' thought processes [5], such that it becomes a meaningful learning [6]. Learning that is close to the daily lives of students is one of the starting points for learning mathematics. Something that becomes a habit of students is local culture. One of them is local music. This can increase mathematical abilities, such as the ability to represent mathematics [7], concept understanding ability [8], problem solving skill [5]. This learning can also minimize students' mistakes in understanding mathematics [9].

Dol music is one of Pariaman Culture. Music contributes to children's cognitive development. Music helps activate the child's motor nerve cells [10]. Like the music that accompanies regional dances. Kejei dance becomes the starting point for students in understanding geometry. Through this music, students have geometric skills. Students identify and classify them in geometric structures. They are able to use models and symbols to represent the concept of geometric shapes [11].

Mathematics and music are interconnected. Mathematical concepts and related basic music include sets, equivalent relations, functions and graphics, integers, rational numbers, real numbers, notes, chords, notes, musical intervals, scales, and key signs [12]. This will increase one's musical intelligence. It was includes sensitivity to rhythm, melody, and tonal colors of the music being enjoyed [13].

Pariaman children are very familiar with Tabuik culture, this is held every year, in the month of Muharram. The Tabuik ceremony has several ritual parts. This always involves Pariaman regional music, which is often referred to as dol music. In the Tabuik Tradition, the dol is a traditional drum which originated from Padang Province, Indonesia. The dol is played by trained men [14]. The Tabuik ceremony commemorates the deaths of Hasan and Husein, the grandchildren of the Prophet Muhammad [15]. Ini adalah masalah kontekstual yang dapat dijadikan titik pangkal pembelajaran matematika. Pendekatan kontekstual merupakan pendekatan yang melibatkan siswa yang aktif dalam proses pembelajaran. Itu 
adalah untuk menemukan atau menemukan kembali konsep berdasarkan pengetahuan sebelumnya dan pengalaman siswa This is a contextual problem that can be used as a starting point for learning mathematics. The contextual approach is an approach that involves students who are active in the learning process. It is to discover or rediscover concepts based on students' previous knowledge and experiences [16].

Language ability through musical chanting can affect the understanding of mathematical concepts. Understanding this concept is a mathematical problem by emphasizing mathematical objects [17]. Mathematical objects include facts, concepts, principles and operations [18]. Concept understanding in this paper is more focused on the ability to understand concepts. The ability to understand concepts is a cognitive ability that includes restating the definition of a concept, classifying objects into a concept, providing examples and not examples of a concept, representing a concept in several forms, developing necessary and sufficient conditions, using certain operations, and applying the concept. in problem solving. [19].

Understanding of mathematical concepts can be achieved better if students learn in a realistic manner. It is one of the elements in understanding mathematical concepts [8]. To improve the understanding of mathematical concepts, learning is needed that supports understanding concepts, namely learning to develop the ability to gather information, analyze information, and make generalizations by applying the process of connection, representation, communication, reasoning and proof, and problem solving [20].

The ability to understand mathematically can be achieved completely if students learn through the ethnomathematics approach [21][5][2][22]. Therefore, the language skills that are practiced through the art of dol music as a local culture allow for an increase in mathematical understanding. It shows the existence of a conceptual diagram as the relationship between language skills and the understanding of math concepts.

Language skills that are sung in music give a person a sense of relaxation. This affects the ability to think academically [23] [24][25]. Thus, language skills mediated by music have an influence on mathematical thinking skills. Therefore, the formulation of the problem of this research is whether the students' language skills through contextual learning based on Padang Tabuik Culture have a positive direct effect on the understanding of mathematical concepts?

\section{METHODS}

This research is a study with a survey approach. This research is designed to test the relationship between language skills through contextual learning based on Padang (Pariaman) Tabuik culture and the understanding of math concepts. The population is all students of SMA N 3 Padang, Indonesia. The number of affordable populations is 389 students. The sample of this research was 100 people. The selection was made through simple random sampling technique. There are two latent variables, namely language skills and the understanding of mathematical concepts. The understanding of math concepts in this study is specifically about the understanding of mathematical concepts. Researchers were carried out when the annual Padang Tabuik Culture activity was underway. Therefore, the entire population reached in this study has followed this learning model. The research instrument was a language proficiency questionnaire and a test of the understanding of mathematical concepts. Data were analyzed using structural equation modeling. Quantitative data were analyzed using a structured equation model. It is analyzed using a Lisrel application program.

\section{RESULTS AND DISCUSSION}

The data from this test is the understanding of mathconcepts (= Pemahama) and language skills (= Berbahas) as a latent variable. Each variable indicator is Listening (X1), Speaking (X2), Reading (X3), and Writing (X4) for Latent Language Ability Variables. The indicator variable for understanding mathematical concepts is $\mathrm{X} 1$ : restates the notion of a concept, X2: classifies objects according to certain concepts, X3: provides examples and not examples of a concept, X4: presents concepts in various forms of representation, X5: arranges necessary and sufficient conditions of a concept, X6: selects an operation, and X7: applies the concept to problem solving. By using the Lisrel 8.8 Application Program, the data were analyzed and presented in Table 1.

Table 1. Goodness of Fit (GOF)

\begin{tabular}{llll}
\hline Statistics & Calculation Results & Criteri-a (fit) & Description \\
\hline Minimum fit function chi-square & $1.35(\mathrm{P}=0.03)$ & $\mathrm{p}>0.05$ & Low \\
RMSEA & 0.0001 & $<0.08$ & Good \\
RMR & 0.023 & $\leq 0.10$ & Good \\
Standarized RMR & 0.037 & $\leq 0.10$ & Good \\
GFI & 0.97 & $\geq 0.90$ & Good \\
AGFI & 0.86 & $0.80 \leq$ AGFI $<0.9$ & Good \\
\hline
\end{tabular}




\begin{tabular}{llll}
\hline Statistics & Calculation Results & Criteri-a (fit) & Description \\
\hline NFI & 0.92 & $\geq 0.90$ & Good \\
NNFI & 0.91 & $\geq 0.90$ & Good \\
CFI & 0.94 & $\geq 0.90$ & Good \\
IFI & 0.97 & $\geq 0.90$ & Good \\
RFI & 0.93 & $\geq 0.90$ & Good \\
PNFI & 0.43 & $\geq 0.00$ & Good \\
\hline
\end{tabular}

Based on Table 1, it is found that all statistical tests meet the fit (good) criteria. It is a theoretical model that fits empirical data (= fit, good). The analysis results show that there are 11 GOF measures that show good compatibility, and only one is not good. The conclusion of this analysis is that the overall model meets the good category. Furthermore, a diagram of the Basic Model Standard Solution can be presented. It can be seen in Figure 1.

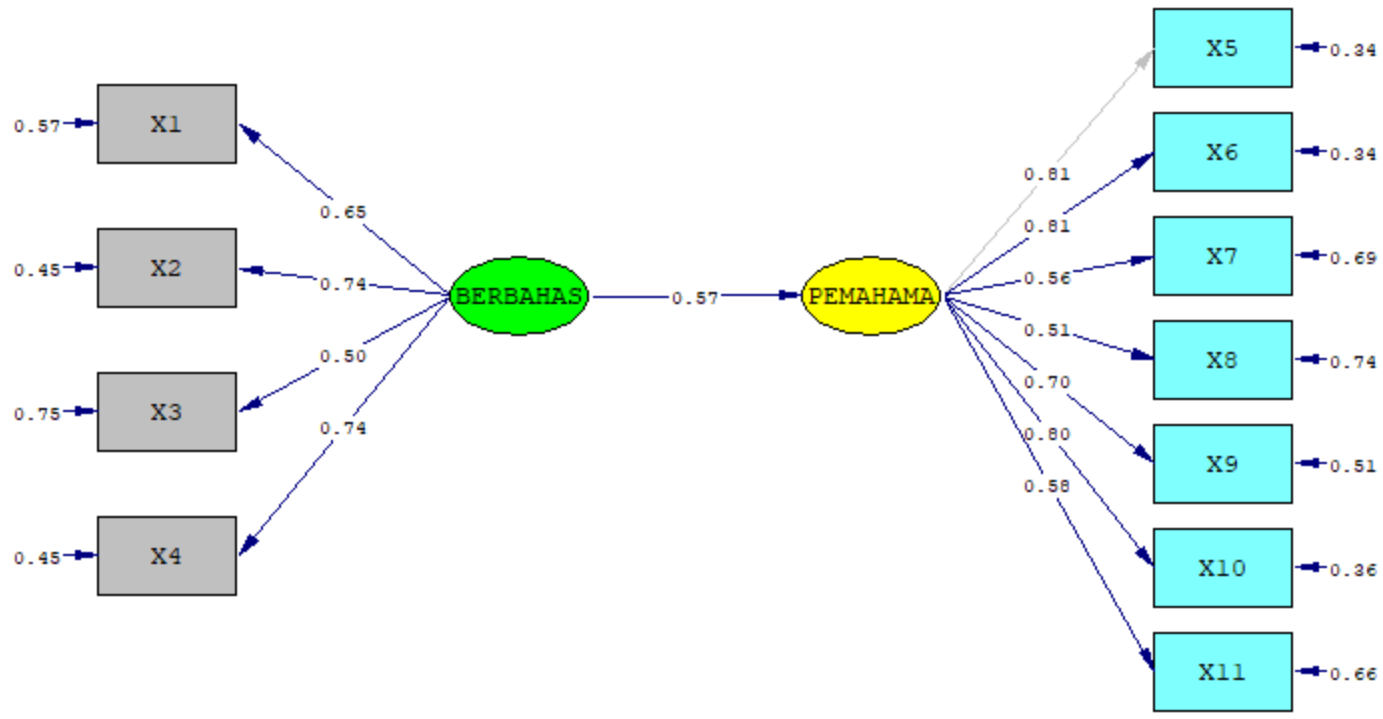

Figure 1. Basic Model Standarized Solution

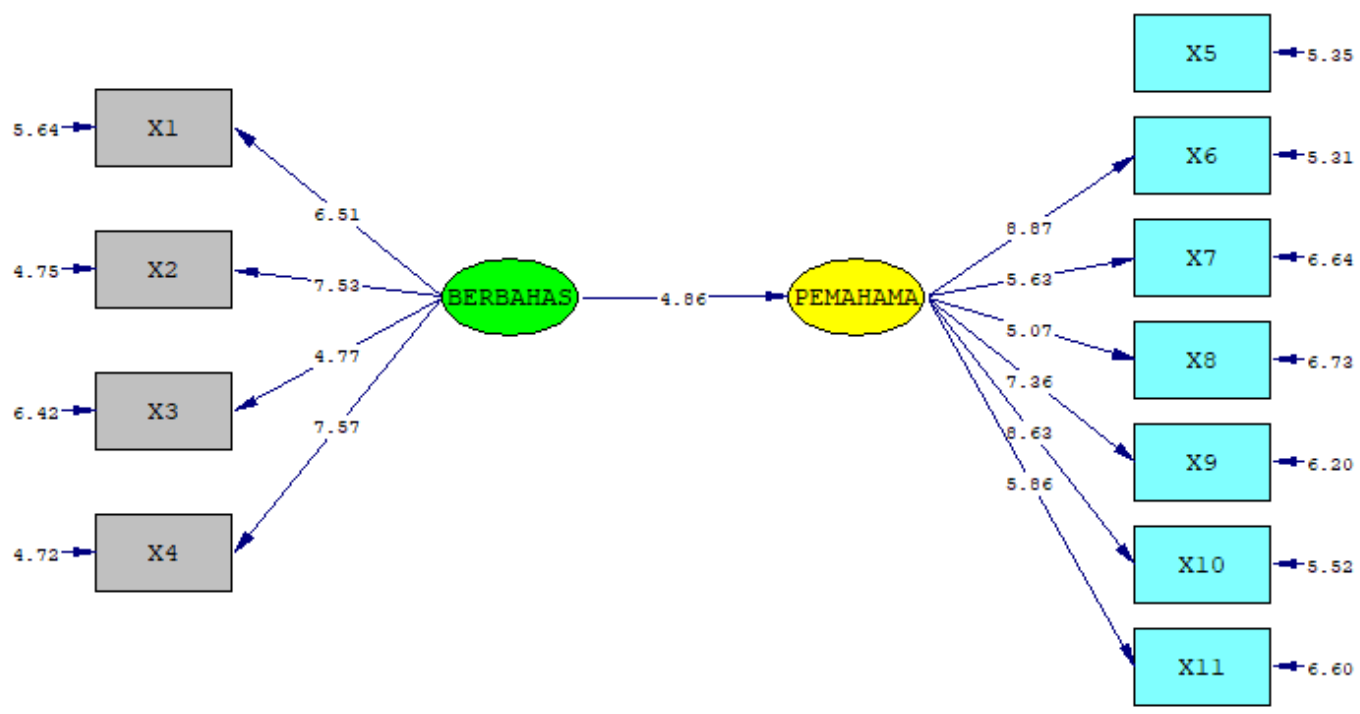

Figure 2. Basic Model to T-Values

The data analysis also presents the Basic Model T-Values path diagram. For more details, please look at Figure 2. Figure 2 and Figure 3 are path diagrams that represent the validity and reliability of two latent variables, namely the ability to speak language and 
understanding mathematical concepts. The results of

the data analysis are presented in Tables 2 and 3.

Table 2. Validity and Reliability of the ability to speak language Indicators

\begin{tabular}{|c|c|c|c|c|c|c|}
\hline \multirow[b]{2}{*}{ Indicator } & \multirow[b]{2}{*}{$\begin{array}{l}\text { SLF } \\
\geq 0.50\end{array}$} & \multirow[b]{2}{*}{$\begin{array}{l}\text { Standard } \\
\text { Errors }\end{array}$} & \multirow[b]{2}{*}{ t-value } & \multirow[b]{2}{*}{$\begin{array}{l}\text { declaratio } \\
\text { n }\end{array}$} & \multicolumn{2}{|c|}{ Reliability } \\
\hline & & & & & $\begin{array}{l}C R \geq \mathbf{0 . 7} \\
\text { 0 }\end{array}$ & $V E \geq \mathbf{0 . 5 0}$ \\
\hline $\mathrm{X} 1$ & 0.65 & 0.57 & 6.51 & Good & \multirow{4}{*}{0.76} & \multirow{4}{*}{0.4} \\
\hline $\mathrm{X} 2$ & 0.74 & 0.45 & 7.52 & Good & & \\
\hline X3 & 0.50 & 0.75 & 4.77 & Good & & \\
\hline $\mathrm{X} 4$ & 0.74 & 0.45 & 7.57 & Good & & \\
\hline $\begin{array}{l}\text { Based } \\
\text { which con } \\
\text { good valid }\end{array}$ & $\begin{array}{l}\text { langu } \\
\text { icator } \\
\text { ates th }\end{array}$ & $\begin{array}{l}\text { ability var } \\
\text { ables has sh } \\
\text { e loading f }\end{array}$ & & $\begin{array}{l}\text { 1.96. Also, } \\
0.70 \text {. The fir } \\
\text { the latent va }\end{array}$ & $\begin{array}{l}\text { e constru } \\
\text { l result s } \\
\text { able of la }\end{array}$ & $\begin{array}{l}\text { reliability } \\
\text { ows that th } \\
\text { guage abil }\end{array}$ \\
\hline
\end{tabular}

Table 3. Validity and Reliability of Indicators of Ability to understand mathematical concepts

\begin{tabular}{|c|c|c|c|c|c|c|}
\hline \multirow{2}{*}{ Indicator } & \multirow{2}{*}{$\begin{array}{c}S L F \geq \\
0.50\end{array}$} & \multirow{2}{*}{$\begin{array}{c}\text { Standard } \\
\text { Errors }\end{array}$} & \multirow{2}{*}{$\begin{array}{c}t \text {-value }> \\
1.96\end{array}$} & \multirow{2}{*}{ Declaration } & \multicolumn{2}{|c|}{ Reliability } \\
\hline & & & & & $\mathrm{CR} \geq \mathbf{0 . 7 0}$ & $V E \geq \mathbf{0 . 5 0}$ \\
\hline $\mathrm{X} 5$ & 8,81 & 0.34 & $* *$ & Good & & \\
\hline X6 & 0.81 & 0.34 & 8.87 & Good & & \\
\hline $\mathrm{X} 7$ & 0.56 & 0.69 & 5.62 & Good & & \\
\hline $\mathrm{X} 8$ & 0.51 & 0.74 & 5.07 & Good & 1.04 & 0.96 \\
\hline X9 & 0.7 & 0.51 & 7.86 & Good & & \\
\hline X10 & 0.8 & 0.36 & 8,63 & Good & & \\
\hline $\mathrm{X} 11$ & 0.56 & 0.69 & 5,86 & Good & & \\
\hline
\end{tabular}

To explain the indicator variable for mathematical thinking skills (understanding mathematical concepts) (see Table 3). Table 3 shows that the validity of the seven observed variables (X5 - X11) on the understanding of mathematical concepts. The seven variables observed were valid. The seven manifest variables are restatement of concept (X5); classify objects according to certain properties according to the concept (X6); shows examples and not examples (X7); represents a concept in various forms (X8); develop a condition which is a sufficient condition of a concept (X9); using, utilizing and selecting specific procedures (X10); and apply the concept to algorithms for problem solving (X11). That is in accordance with the provisions of the loading factor value of more than 0.50 and the $t$ value of not less than 1.96. For reliability, the CR value is 1.04 over 0.70 . which shows that the reliability test of the mathematics ability variable produces good scores. The conclusion is that understanding mathematical concepts has good consistency.

Based on the validity and reliability tests and Figure 2. Basic Model T-Values, hypotheses can be tested about the direct effect of students' language skills through contextual learning based on Padang Tabuik Culture on the understanding of mathematical concepts. The test shows that $\mathrm{t}=4.86$ with $\mathrm{p}$ value $=$ 0.00 . This means that there is a positive direct influence on students' language skills through contextual learning based on the Tabuik Padang Culture on their ability to understand mathematical concepts. The results of this study are in line with other studies. Musical ability has a positive direct effect on the native abstraction ability of low-level elementary students [26]. Ethnomathematics based mathematics learning and a connected mathematics approach have a positive impact on students' cognitive processes [27]. Students have the ability to understand multiplication and division operations. Also, able to communicate verbally, in writing, and mathematical representations. It is based on real media based on local culture [28]. Thus, it is true that language skills through contextual learning based on local culture have an effect on the understanding of math concepts. 


\section{CONCLUSION}

We conclude that there is a positive direct effect of students' language skills through contextual (culture-based) learning on their ability to understand mathematical concepts. This is supported by the validity and reliability of the indicators of the two variables (namely language skills and the understanding of mathematical concepts). Therefore, to improve mathematical thinking skills, educators must apply contextual learning based on local culture.

\section{REFERENCES}

[1] D. Herawaty and W. Widada, "The Influence of Contextual Learning Models and the Cognitive Conflict to Understand Mathematical Concepts and Problems Solving Abilities," Adv. Soc. Sci. Educ. Humanit. Res., vol. 218, no. ICoMSE 2017, pp. 96-102, 2018.

[2] D. Herawaty, W. Widada, K. Umam, Z. Nugroho, A. Falaq, and D. Anggoro, "The Improvement of the Understanding of Mathematical Concepts through the Implementation of Realistic Mathematics Learning and Ethnomathematics," Adv. Soc. Sci. Educ. Humanit. Res. Vol. 295, vol. 295, no. ICETeP 2018, pp. 21-25, 2019.

[3] A. Treffers, "Didactical background of a mathematics programm for primary education," Utrecht: Freudenthal Institute, 1991.

[4] J. De Lange, Mathematics insight and Meaning. Utrech: OW \& OC, 1987.

[5] W. Widada, D. Herawaty, A. Falaq, D. Anggoro, A. Yudha, and M. K. Hayati, "Ethnomathematics and Outdoor Learning to Improve Problem Solving Ability," Adv. Soc. Sci. Educ. Humanit. Res. Vol. 295, vol. 295, no. ICETeP 2018, pp. 13-16, 2019.

[6] D. P. Ausubel, "The use of advance organizers in the learning and retention of meaningful verbal material," J. Educ. Psychol., vol. 51, pp. 267-272, 1960.

[7] W. Widada, K. U. Z. Nugroho, W. P. Sari, and G. A. Pambudi, "The ability of mathematical representation through realistic mathematics learning based on ethnomathematics," J. Phys. Conf. Ser., vol. 1318, no. 012073, pp. 1-8, 2019.

[8] W. Widada, A. Agustina, S. Serlis, B. M. Dinata, and S. T. Hasari, "The abstraction ability of students in understanding the concept of geometry The abstraction ability of students in understanding the concept of geometry," J. Phys. Conf. Ser., vol. 1318, no. 012082, pp. 1-7, 2019.

[9] D. Herawaty, S. A. Gusri, R. Saputra, E. Liana, and F. Aliza, "The mathematics communication of students in learning based on ethnomathematics Rejang Lebong," $J$. Phys. Conf. Ser. Pap., vol. 1318, no. 012074, pp. 1-8, 2019.

[10] Anonimous, "Menyeimbangkan Otak Kanan Dan Otak Kiri Dengan Musik Klasik," https://dutanada.com/artikel-pendidikan/149menyeimbangkan- otak-kanan-dan-otak-kiridengan-musik-klasik.html, vol. 2, pp. 6-11, 2018 .

[11] N. Ma'Rifah, W. Widada, A. Aida, Y. Yulfitri, and J. Effendi, "The students , mathematics understanding through ethnomathematics based on kejei dance," $J$. Phys. Conf. Ser., vol. 1318, no. 012079, pp. $1-6,2019$.

[12] D. Wright, Mathematics and Music. St. Louis: Washington University, 2009.

[13] Anonimous, ",", https://edukasi.kompas.com/read/2018/05/22/ , 2018.

[14] Anonimous, "id.wikipedia.org > wiki > Dol." 2020.

[15] Anonimous, https://lifestyle.okezone.com/read/2017/10/06 1406/1789878/ mengenal-dol-alat-musikkhas-bengkulu-yang-mendunia, vol. 13, no. 3 , pp. 1576-1580. 2017.

[16] D. Selvianiresa and S. Prabawanto, "Contextual Teaching and Learning Approach of Mathematics in Primary Schools," J. Phys. Conf. Ser., vol. 895, no. 1, 2017.

[17] S. Mustafa and V. Sari, "Deskripsi Kemampuan Berpikir Matematis Siswa dengan Menggunakan Worksheet," Pros. (ISSN 2501-6526), vol. PM-34, no. Prosiding, pp. 546-554, 2017.

[18] W. Widada, D. Herawaty, K. U. Z. Nugroho, and A. F. D. Anggoro, "The ability to Understanding of the Concept of Derivative Functions for Inter-Level Students During Ethnomathematics Learning," J. Phys. Conf. Ser., vol. 1179, no. 012056, pp. 1-6, 2019.

[19] S. Suharto and W. Widada, "The Cognitive Structure of Students in Understanding Mathematical Concepts," Adv. Soc. Sci. 
Educ. Humanit. Res. Vol. 295, vol. 295, no. ICETeP 2018, pp. 65-69, 2019.

[20] U. Layyina, "Analisis Kemampuan Berpikir Matematis Berdasarkan Tipe Kepribadian pada Model 4K dengan Asesmen Proyek Bagi Siswa Kelas VII," Prisma, vol. 1, pp. 704-713, 2018.

[21] D. Herawaty, W. Widada, T. Novita, L. Waroka, and A. N. M. T. Lubis, "Students' metacognition on mathematical problem solving through ethnomathematics in Rejang Lebong, Indonesia," J. Phys. Conf. Ser., vol. 1088, 2018.

[22] W. Widada, D. Herawaty, N. Ma'rifah, and D. Yunita, "Characteristics of Students Thinking in Understanding Geometry in Learning Ethnomathematics," Int. J. Sci. Technol. Res., vol. 8, no. 11, pp. 3496-3503, 2019.

[23] N. S. Hidayat, "Hubungan berbahasa, berpikir, dan berbudaya," Sos. Budaya, vol. 11, no. 2, pp. 190-205, 2014.

[24] M. Fajri, "Kemampuan Berpikir Matematis Dalam Konteks Pembelajaran Abad 21 Di Sekolah Dasar," J. LEMMA, vol. 3, no. 1, pp.
$1-11,2017$.

[25] E. T. Suhendi, "Berbahasa, berpikir, dan peran pendidikan bahasa," Proc. Educ. Lang. Int. Conf., vol. 1, no. 1, pp. 298-305, 2017.

[26] D. Herawaty, W. Widada, H. Ardy, R. Furqany, and A. F. D. Anggoro, "The abstraction ability about natural numbers through playing traditional music for elementary students," Int. Semin. Appl. Math. Math. Educ. 2020 (2nd ISAMME 2020). J. Phys. Conf. Ser., vol. 1657, no. 012039, pp. 1-6, 2020.

[27] W. Widada, D. Herawaty, I. Hudiria, Y. A. Prakoso, Y. R. Anggraeni, and K. U. Zaid, "The understanding of the triangle in Lobachevsky Geometry through local culture," Int. Semin. Appl. Math. Math. Educ. 2020 (2nd ISAMME 2020). J. Phys. Conf. Ser., vol. 1657, no. 012038, pp. 1-7, 2020.

[28] W. Widada, D. Herawaty, Y. Pusvita, D. Anggreni, R. Aripianti, and B. Panduwinata, "Multiplication and division of integers through cultural approaches of playing dakon," Int. Semin. Appl. Math. Math. Educ. 2020 (2nd ISAMME 2020), J. Phys. Conf. Ser., vol. 1657, no. 012030. pp. 1-9, 2020. 